\title{
EFFECT OF NPK FERTILIZATION AND MICRONUTRIENTS ON DELONIX REGIA SEEDLINGS GROWN IN SANDY SOIL
}

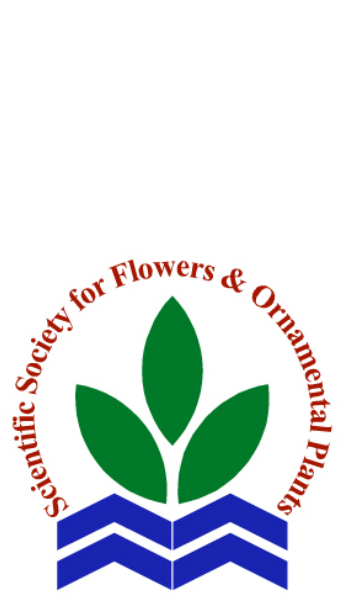

Scientific J. Flowers \& Ornamental Plants, 5(2):151-159 (2018).

Received: 2/3/2018

Accepted: $13 / 3 / 2018$

\author{
M.A.H. Abdou and F.S. Badran
}

Hort. Dept., Fac. Agric., Minia Univ., Egypt.

\begin{abstract}
A pot experiment was carried out to study the effect of different NPK fertilization rates and various $\mathrm{Mn}$ and $\mathrm{Zn}$ treatments on sandy soil-grown Delonix regia seedlings at the Nursery of Fac. of agric., Minia Univ. during 2016 and 2017 seasons.

The obtained results showed that following: all studied vegetative growth characters, i.e. plant height, stem thickness, crown diameter and leaves, stem and roots dry weights, as well as, the three photosynthetic pigments and leaves \% of $\mathrm{N}, \mathrm{P}$ and $\mathrm{K}$ were gradually increased upward parallel to the increase in the applied rate of NPK fertilizers. Similarly, the prementioned vegetative growth and chemical parameters were augmented due to the use of $\mathrm{Mn}+\mathrm{Zn}$ micronutrient treatments with the effective one being Mn 75 ppm + Zn 75 ppm. It was found that supplying the seedlings with either the medium or high $\mathrm{NPK}$ rate combined with $\mathrm{Mn}$ at $75 \mathrm{ppm}+\mathrm{Zn}$ at $75 \mathrm{ppm}$ was capable of producing the best growth of Delonix regia seedlings grown in sandy soil.
\end{abstract}

Key words: Delonix regia, NPK fertilization, Mn, Zn, vegetative growth, photosynthetic pigments.

\section{INTRODUCTION}

The nutritional requirements, in term of macro and microelements, for many ornamental trees grown in clay and loamy soils, had been extensively carried out. However, those grown under sandy soil conditions deserve more investigations, especially in Egyptian new towns and villages extended in the newly reclaimed regions.

Delonix regia (royal poinciana) is one of the most popular shady ornamental trees. It is the most popular shady ornamental trees. It is fast growing deciduous tree reaching 6$12 \mathrm{~m}$. height. Leaves are $30-50 \mathrm{~cm}$ long with 20-40 pairs of oblong leaflets. The tree is almost completely covered with red showy flower 6-10 cm across during summer and autumn. In addition to the very nice structural tent-like canopy 8-10 m across.
The distinctive roles of $\mathrm{N}, \mathrm{P}$ and $\mathrm{K}$ fertilizers in enhancing the various vegetative growth characters and stimulating chemical constituents of different ornamental woody plants were found by Badran et al. (2003) on Acacia saligna, Ali (2005) on Sterculia diversifolia, Abdou et al. (2006) on Khaya senegalensis, El-Sayed et al. (2006) on Dalbergia sissoo, Badran et al. (2008) on Koelreuteria paniculata, Shetta et al. (2014) on Leucaena, Abd-Elmola (2014) on poplar and Badran et al. (2016) on Moringa oleifera. However, those of $\mathrm{Mn}$ and $\mathrm{Zn}$ were declared by Badran et al. (1989) on Luffa cylindrica; Taha (1994) on Parkinsonia aculeata; Badran et al. (1994), Aly et al. (1994), Ahmed (1995) and Ahmed and Aly (1998) on Leucaena; Al-Humaid (1998) on rose and Mahdy (2002) on Albizzia lebbek. 


\section{MATERIALS AND METHODS}

A pot experiment was conducted during 2016 and 2017 successive seasons at the Nursery of Fac. of Agric., Minia Univ. to study the effect of three NPK fertilization rates and five zinc plus manganese levels on vegetative growth, photosynthetic pigments content and leaves N, P and K \% of Delonix regia seedlings grown in sandy soil.

One year old seedlings (average of 80 $\mathrm{cm}$ height and $8 \mathrm{~mm}$ diameter) were planted in $30 \mathrm{~cm}$ clay pots filled with $12 \mathrm{~kg}$ sandy soil on the second week of March for both seasons. A complete randomized block design in split-plot arrangement, with four replicates and five plants/replicate, was followed where three NPK fertilization rates represented the main plots and five micronutrient treatments occupied the subplots.

The three NPK treatments were $\mathrm{N}_{1} \mathrm{P}_{1} \mathrm{~K}_{1}$, $\mathrm{N}_{2} \mathrm{P}_{2} \mathrm{~K}_{2}$ and $\mathrm{N}_{3} \mathrm{P}_{3} \mathrm{~K}_{3}$ where the amounts of $\mathrm{N}_{1}, \mathrm{~N}_{2}$ and $\mathrm{N}_{3}$ were 12, 24 and 36 g/pot of ammonium sulphate $(20.5 \% \mathrm{~N}) ; \mathrm{P}_{1}, \mathrm{P}_{2}$ and $\mathrm{P}_{3}$ were 10,20 and $30 \mathrm{~g} /$ pot of calcium superphosphate (15.5 \% $\mathrm{P}_{2} \mathrm{O}_{5}$ ) and $\mathrm{K}_{1}, \mathrm{~K}_{2}$ and $\mathrm{K}_{3}$ were 5, 10 and $15 \mathrm{~g} /$ pot of potassium sulphate $\left(\begin{array}{lll}48 & \% & \mathrm{~K}_{2} \mathrm{O}\end{array}\right)$. Such fertilizer amounts were divided into four equal portions and added two months after planting date, with four weeks intervals thereafter. On the other side, $\mathrm{Zn}$ and $\mathrm{Mn}$ were foliar sprayed as zinc sulphate and manganese sulphate at the concentration of 25, 50, 75 and $100 \mathrm{ppm}$ for each element, in addition to the control. Such five treatments were applied four times, with three weeks interval, three months after planting date.

On the second week of October for both seasons, data were recorded for plant height, stem thickness, crown diameter and leaves, stem and roots dry weight. In addition, chlorophyll a, b and carotenoids contents according to Fadl and Seri-Eldeen (1978) and leaves $\mathrm{N}, \mathrm{P}$ and $\mathrm{K} \%$ according to Page et al. (1982) were determined. All obtained data were statistically analyzed following the method of Little and Hills (1978).

\section{RESULTS AND DISCUSSION}

\section{Vegetative growth parameters:}

All studied vegetative growth parameters were gradually increased parallel to the increase in the applied NPK rate, in both seasons. Within the three NPK rates both medium $\left(\mathrm{N}_{2} \mathrm{P}_{2} \mathrm{~K}_{2}\right)$ and high $\left(\mathrm{N}_{3} \mathrm{P}_{3} \mathrm{~K}_{3}\right)$ ones gave significantly higher values than the low one $\left(\mathrm{N}_{1} \mathrm{P}_{1} \mathrm{~K}_{1}\right)$ for plant height, stem thickness, crown diameter and stem dry weight with no significant differences between the medium and high ones as shown

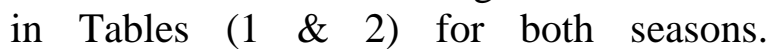
Numerically, plant height, stem thickness and crown diameter were increased by 15.6 , 10.4 and $13.6 \%$ in the first season and 15.3, 10.8 and $14.3 \%$ in the second one due the high rate over the low one. In agreement with these results were those of Badran et al. (2003) on Acacia saligna, El-Sayed et al. (2006) on Dalbergia sissoo, Abdou et al. (2006) on Khaya senegalensis, Badran et al. (2008) on Koelreuteria paniculata, Shetta et al. (2010) on Leucaena and Badran et al. (2016) on Moringa oleifera.

Table a. Physical and chemical analysis of the used soil.

\begin{tabular}{|c|c|c|c|}
\hline Properties & Values & Properties & Values \\
\hline Sand (\%) & 91.0 & P mg/100 (g) & 3.92 \\
\hline Silt (\%) & 5.8 & Exchangeable $\mathrm{K}^{+} \mathrm{mg} / 100 \mathrm{~g}$ soil & 0.21 \\
\hline Clay (\%) & 3.2 & $\mathbf{F e}$ & 1.22 \\
\hline Organic matter (\%) & 0.08 & DTPA & 0.44 \\
\hline $\mathrm{CaCO}_{3}(\%)$ & 12.7 & Ext. (ppm) & 0.23 \\
\hline pH (1:2.5) & 8.12 & Mn & 0.41 \\
\hline E.C. mmhose/cm & 1.09 & & \\
\hline Total N (\%) & 0.02 & & \\
\hline
\end{tabular}


Table 1. Effect of NPK and micronutrient fertilization treatments on plant height, stem thickness and crown diameter of Delonix regia seedlings during 2016 and 2017 seasons.

\begin{tabular}{|c|c|c|c|c|c|c|c|c|}
\hline \multirow{3}{*}{$\begin{array}{l}\text { Micro nutrient } \\
\text { treatments (B) }\end{array}$} & \multicolumn{8}{|c|}{ NPK fertilization rates (A) } \\
\hline & \multicolumn{4}{|c|}{$1^{\text {st }}$ season (2016) } & \multicolumn{4}{|c|}{$2^{\text {nd }}$ season $(2017)$} \\
\hline & $\mathbf{N}_{1} \mathbf{P}_{1} \mathbf{K}_{1}$ & $\mathbf{N}_{2} \mathbf{P}_{2} \mathbf{K}_{2}$ & $\mathbf{N}_{3} \mathbf{P}_{3} \mathbf{K}_{3}$ & Mean (B) & $\mathbf{N}_{\mathbf{1}} \mathbf{P}_{\mathbf{1}} \mathbf{K}_{\mathbf{1}}$ & $\mathbf{N}_{2} \mathbf{P}_{2} \mathbf{K}_{2}$ & $\mathbf{N}_{3} \mathbf{P}_{3} \mathbf{K}_{3}$ & Mean (B) \\
\hline \multicolumn{9}{|c|}{ Plant height (cm) } \\
\hline Control & 122 & 134 & 139 & 132 & 125 & 137 & 143 & 135 \\
\hline Mn $25+$ Zn 25 & 140 & 161 & 163 & 155 & 144 & 162 & 165 & 157 \\
\hline Mn $50+$ Zn 50 & 145 & 164 & 166 & 158 & 148 & 168 & 170 & 162 \\
\hline Mn 75 + Zn 75 & 153 & 175 & 177 & 168 & 156 & 174 & 178 & 169 \\
\hline Mn $100+$ Zn 100 & 147 & 165 & 169 & 160 & 149 & 167 & 172 & 163 \\
\hline Mean (A) & 141 & 160 & 163 & & 144 & 162 & 166 & \\
\hline L.S.D. at $5 \%$ & A: 12 & & 10 & AB: 17 & A: 10 & & B: 8 & AB: 14 \\
\hline \multicolumn{9}{|c|}{ Stem thickness (mm) } \\
\hline Control & 11.4 & 12.5 & 13.5 & 12.5 & 11.6 & 12.9 & 13.6 & 12.7 \\
\hline Mn $25+$ Zn 25 & 15.2 & 16.8 & 17.2 & 16.4 & 15.8 & 17.2 & 17.8 & 16.9 \\
\hline Mn $50+$ Zn 50 & 16.8 & 17.7 & 18.0 & 17.5 & 17.2 & 17.7 & 18.4 & 17.8 \\
\hline Mn 75 + Zn 75 & 17.1 & 17.9 & 18.4 & 17.8 & 17.5 & 18.6 & 19.4 & 18.5 \\
\hline Mn $100+$ Zn 100 & 16.6 & 17.4 & 17.9 & 17.3 & 16.7 & 17.6 & 18.2 & 17.5 \\
\hline Mean (A) & 15.4 & 16.5 & 17.0 & & 15.8 & 16.8 & 17.5 & \\
\hline L.S.D. at $5 \%$ & A: 0.8 & & 1.2 & AB: 2.1 & A: 0.9 & & B: 1.4 & AB: 2.4 \\
\hline \multicolumn{9}{|c|}{ Crown diameter $(\mathrm{m})$} \\
\hline Control & 1.65 & 1.72 & 1.76 & 1.71 & 1.73 & 1.78 & 1.84 & 1.78 \\
\hline Mn $25+$ Zn 25 & 1.90 & 2.11 & 2.18 & 2.06 & 1.94 & 2.09 & 2.21 & 2.08 \\
\hline Mn $50+$ Zn 50 & 1.96 & 2.20 & 2.24 & 2.13 & 2.00 & 2.31 & 2.34 & 2.22 \\
\hline Mn $75+$ Zn 75 & 2.06 & 2.36 & 2.41 & 2.28 & 2.12 & 2.39 & 2.48 & 2.33 \\
\hline Mn $100+$ Zn 100 & 1.98 & 2.22 & 2.28 & 2.16 & 2.03 & 2.29 & 2.33 & 2.22 \\
\hline Mean (A) & 1.91 & 2.12 & 2.17 & & 1.96 & 2.17 & 2.24 & \\
\hline L.S.D. at $5 \%$ & A: 0.10 & & 0.12 & AB: 0.21 & A: 0.13 & & 3: 0.14 & AB: 0.24 \\
\hline
\end{tabular}

Concerning micronutrient treatments, each of plant height, stem thickness, crown diameter and leaves and stem dry weights were significantly increased due to all applied micronutrient concentrations in comparison with control treatment. Such increase was gradually parallel to the increase in $\mathrm{Mn}+\mathrm{Zn}$ concentration up to 75 ppm. Such trend was evident in the two seasons as shown in Tables (1 and 2). The best treatment $(\mathrm{Mn}$ at $75 \mathrm{ppm}+\mathrm{Zn}$ at 75 ppm) increased plant height, stem thickness, leaves crown diameter, leaves dry weight and stem dry weight, respectively, by 27.3, 42.4, 33.3, 32.4 and $32.7 \%$ in comparison with the values of the control treatment in the first season. Nearly similar values were almost obtained in the second season for the same respective traits and treatments. In accordance with these results were the findings of Badran et al. (1989) on Luffa cylindrica; Taha (1994) on Parkinsonia 
Table 2. Effect of NPK and micronutrient fertilization treatments on the dry weights of leaves, stem and roots of Delonix regia seedlings during 2016 and 2017 seasons.

\begin{tabular}{|c|c|c|c|c|c|c|c|c|}
\hline \multirow{3}{*}{$\begin{array}{l}\text { Micro nutrient } \\
\text { treatments (B) }\end{array}$} & \multicolumn{8}{|c|}{ NPK fertilization rates (A) } \\
\hline & \multicolumn{4}{|c|}{$1^{\text {st }}$ season (2016) } & \multicolumn{4}{|c|}{$2^{\text {nd }}$ season $(2017)$} \\
\hline & $\mathbf{N}_{1} \mathbf{P}_{1} \mathbf{K}_{1}$ & $\mathbf{N}_{2} \mathbf{P}_{2} \mathbf{K}_{2}$ & $\mathbf{N}_{3} \mathbf{P}_{3} \mathbf{K}_{3}$ & Mean (B) & $\mathbf{N}_{\mathbf{1}} \mathbf{P}_{\mathbf{1}} \mathbf{K}_{\mathbf{1}}$ & $\mathbf{N}_{2} \mathbf{P}_{2} \mathbf{K}_{2}$ & $\mathbf{N}_{3} \mathbf{P}_{3} \mathbf{K}_{3}$ & Mean (B) \\
\hline \multicolumn{9}{|c|}{ Leaves dry weight (g) } \\
\hline Control & 59.8 & 64.3 & 66.6 & 63.6 & 63.3 & 68.0 & 70.5 & 67.3 \\
\hline Mn $25+$ Zn 25 & 70.8 & 72.6 & 74.2 & 72.5 & 73.7 & 76.7 & 78.6 & 76.3 \\
\hline Mn $50+$ Zn 50 & 77.6 & 79.4 & 81.8 & 79.6 & 82.0 & 85.3 & 88.6 & 85.3 \\
\hline Mn $75+$ Zn 75 & 82.0 & 84.7 & 85.9 & 84.2 & 87.2 & 88.8 & 90.3 & 38.8 \\
\hline Mn $100+$ Zn 100 & 77.9 & 81.6 & 82.4 & 80.6 & 81.8 & 84.4 & 87.1 & 84.4 \\
\hline Mean (A) & 73.6 & 76.5 & 78.2 & & 77.6 & 80.6 & 83.0 & \\
\hline L.S.D. at $5 \%$ & A: N.S. & & 5.6 & AB: 9.7 & A: N.S & & 3: 7.0 & AB: 12.1 \\
\hline \multicolumn{9}{|c|}{ Stem dry weight (g) } \\
\hline Control & 24.2 & 27.4 & 29.9 & 27.9 & 26.2 & 28.4 & 31.1 & 28.6 \\
\hline Mn $25+$ Zn 25 & 29.8 & 34.3 & 36.6 & 33.6 & 30.3 & 34.9 & 36.5 & 33.9 \\
\hline Mn $50+$ Zn 50 & 31.7 & 34.9 & 37.0 & 34.5 & 33.8 & 36.3 & 37.2 & 35.8 \\
\hline Mn $75+$ Zn 75 & 32.8 & 37.5 & 37.9 & 36.1 & 35.1 & 38.8 & 39.8 & 37.9 \\
\hline Mn $100+$ Zn 100 & 31.1 & 35.3 & 35.8 & 34.1 & 34.2 & 35.3 & 37.3 & 35.6 \\
\hline Mean (A) & 29.9 & 33.9 & 35.4 & & 31.9 & 34.7 & 36.4 & \\
\hline L.S.D. at $5 \%$ & A: 2.4 & & 2.7 & AB: 4.7 & A: 2.0 & & A: 2.8 & B: 4.9 \\
\hline \multicolumn{9}{|c|}{ Roots dry weight (g) } \\
\hline Control & 112 & 118 & 122 & 117 & 115 & 121 & 124 & 120 \\
\hline Mn $25+$ Zn 25 & 114 & 123 & 125 & 121 & 119 & 124 & 128 & 124 \\
\hline Mn $50+$ Zn 50 & 118 & 124 & 127 & 123 & 122 & 127 & 130 & 126 \\
\hline Mn $75+$ Zn 75 & 122 & 126 & 131 & 126 & 126 & 130 & 135 & 130 \\
\hline Mn $100+$ Zn 100 & 119 & 123 & 128 & 123 & 121 & 128 & 131 & 127 \\
\hline Mean (A) & 117 & 123 & 127 & & 121 & 126 & 130 & \\
\hline L.S.D. at 5 \% & A: N.S. & & N.S. & AB: N.S. & A: N.S & & N.S. & AB: N.S. \\
\hline
\end{tabular}

aculata, Badran et al. (1994), Ahmed (1995) and Ahmed et al. (1998) on Leucaena and Mahdy (2002) on Albizzia lebbek.

The interaction between NPK and microelement treatments was significant in both seasons for all studied vegetative growth characters except for roots dry weight as indicated in Tables (1 and 2). The best results were obtained due to $\mathrm{N}_{2} \mathrm{P}_{2} \mathrm{~K}_{2}$ or $\mathrm{N}_{3} \mathrm{P}_{3} \mathrm{~K}_{3}$ in combination with the treatment of $\mathrm{Mn}$ at $75 \mathrm{ppm}+\mathrm{Zn}$ at $75 \mathrm{ppm}$ as clearly shown in Tables (1 and 2).

\section{Photosynthetic pigments content:}

The three photosynthetic pigments, i.e. chlorophyll a, b and carotenoids were gradually increased, in both seasons, according to the gradual increase in NPK rate. Significant differences were detected with the highest values being obtained due to the high rate $\left(\mathrm{N}_{3} \mathrm{P}_{3} \mathrm{~K}_{3}\right)$ for the three pigments as indicated in Table (3). The beneficial role 
Table 3. Effect of NPK and micronutrient fertilization treatments on the contents of photosynthetic pigments of Delonix regia seedlings during 2016 and 2017 seasons.

\begin{tabular}{|c|c|c|c|c|c|c|c|c|}
\hline \multirow{3}{*}{$\begin{array}{l}\text { Micro nutrient } \\
\text { treatments (B) }\end{array}$} & \multicolumn{8}{|c|}{ NPK fertilization rates (A) } \\
\hline & \multicolumn{4}{|c|}{$1^{\text {st }}$ season (2016) } & \multicolumn{4}{|c|}{$2^{\text {nd }} \operatorname{season}(2017)$} \\
\hline & $\mathbf{N}_{1} \mathbf{P}_{1} \mathbf{K}_{1}$ & $\mathbf{N}_{2} \mathbf{P}_{2} \mathbf{K}_{2}$ & $\mathbf{N}_{3} \mathbf{P}_{3} \mathbf{K}_{3}$ & Mean (B) & $\mathbf{N}_{1} \mathbf{P}_{1} \mathbf{K}_{1}$ & $\mathbf{N}_{2} \mathbf{P}_{2} \mathbf{K}_{2}$ & $\mathbf{N}_{3} \mathbf{P}_{3} \mathbf{K}_{3}$ & Mean (B) \\
\hline \multicolumn{9}{|c|}{ Chlorophyll a content (mg/g f.w.) } \\
\hline Control & 2.24 & 2.28 & 2.33 & 2.28 & 2.29 & 2.32 & 2.37 & 2.33 \\
\hline Mn $25+$ Zn 25 & 2.28 & 2.31 & 2.37 & 2.32 & 2.32 & 2.36 & 2.39 & 2.36 \\
\hline Mn $50+$ Zn 50 & 2.30 & 2.32 & 2.39 & 2.34 & 2.35 & 2.39 & 2.42 & 2.39 \\
\hline Mn $75+$ Zn 75 & 2.34 & 2.38 & 2.42 & 2.38 & 2.38 & 2.40 & 2.46 & 2.41 \\
\hline Mn $100+$ Zn 100 & 2.28 & 2.30 & 2.36 & 2.31 & 2.34 & 2.39 & 2.40 & 2.38 \\
\hline Mean (A) & 2.29 & 2.32 & 2.37 & & 2.34 & 2.37 & 2.41 & \\
\hline L.S.D. at $5 \%$ & A: 0.05 & \multicolumn{2}{|c|}{ B: N.S. } & AB: N.S. & \multicolumn{2}{|c|}{ A: 0.04} & B: N.S. & AB: N.S. \\
\hline \multicolumn{9}{|c|}{ Chlorophyll b content (mg/g f.w.) } \\
\hline Control & 1.08 & 1.18 & 1.20 & 1.15 & 1.11 & 1.20 & 1.24 & 1.18 \\
\hline Mn $25+$ Zn 25 & 1.11 & 1.23 & 1.23 & 1.19 & 1.14 & 1.24 & 1.28 & 1.22 \\
\hline Mn $50+$ Zn 50 & 1.14 & 1.26 & 1.25 & 1.22 & 1.17 & 1.26 & 1.30 & 1.24 \\
\hline Mn $75+$ Zn 75 & 1.18 & 1.30 & 1.32 & 1.27 & 1.22 & 1.29 & 1.33 & 1.28 \\
\hline Mn $100+$ Zn 100 & 1.15 & 1.28 & 1.28 & 1.24 & 1.20 & 1.28 & 1.31 & 1.26 \\
\hline Mean (A) & 1.13 & 1.25 & 1.26 & & 1.17 & 1.25 & 1.29 & \\
\hline L.S.D. at $5 \%$ & A: 0.04 & & 0.04 & AB: 0.07 & A: 0.03 & & 0.04 & AB: 0.07 \\
\hline \multicolumn{9}{|c|}{ Carotenoids content (mg/g f.w.) } \\
\hline Control & 1.44 & 1.58 & 1.67 & 1.56 & 1.54 & 1.60 & 1.71 & 1.62 \\
\hline Mn $25+$ Zn 25 & 1.49 & 1.66 & 1.71 & 1.62 & 1.60 & 1.64 & 1.73 & 1.66 \\
\hline Mn $50+$ Zn 50 & 1.51 & 1.67 & 1.73 & 1.64 & 1.66 & 1.69 & 1.75 & 1.70 \\
\hline Mn $75+$ Zn 75 & 1.62 & 1.75 & 1.78 & 1.72 & 1.71 & 1.77 & 1.80 & 1.76 \\
\hline Mn $100+$ Zn 100 & 1.48 & 1.71 & 1.74 & 1.64 & 1.68 & 1.73 & 1.76 & 1.72 \\
\hline Mean (A) & 1.51 & 1.67 & 1.73 & & 1.64 & 1.69 & 1.75 & \\
\hline L.S.D. at $5 \%$ & A: 0.05 & & 0.06 & AB: N.S. & A: 0.04 & & 0.04 & AB: N.S. \\
\hline
\end{tabular}

of NPK fertilization in promoting the photosynthetic pigments was revealed also by Badran et al. (2003), Ali (2005), Abdou et al. (2006), Abd-Elmola (2014) and Badran et al. (2016) on Acacia saligna, Sterculia diversifolia, Khaya senegalensis, poplar and Moringa oleifera, respectively.

In regard to micronutrients, the contents of the three photosynthetic pigments were gradually increased by the gradual increase in the micronutrients concentration up to $\mathrm{Mn}$ $75 \mathrm{ppm}+\mathrm{Zn}$ at $75 \mathrm{ppm}$ in both seasons.
However, significant differences were detected for chlorophyll $b$ and carotenoids only as shown in Table (3) with the highest values being given by Mn 75 ppm + Zn 75 ppm. In accordance with these results were the findings of Badran et al. (1989) on Luffa cylindrica, Taha (1994) on Parkinsonia aculeata, Ahmed (1995) and Ahmed and Aly (1998) on Leucaena and Mahdy (2002) on Albizzia lebbek.

Table (3) shows that the interaction between NPK and Mn/Zn treatments did not 
reach the level of significance, in the two seasons, except for that of chlorophyll b.

\section{Leaves percent of nitrogen, phosphorus} and potassium:

Table (4) illustrates that both medium and high NPK rates significantly augmented each of $\mathrm{N}, \mathrm{P}$ and $\mathrm{K}$ leaves \%, in both seasons, over those of the low rate. It is interesting to note that non-significant differences were existed between medium $\left(\mathrm{N}_{2} \mathrm{P}_{2} \mathrm{~K}_{2}\right)$ and high $\left(\mathrm{N}_{3} \mathrm{P}_{3} \mathrm{~K}_{3}\right)$ rates in this concern. The findings of Ali (2005), ElSayed et al. (2006), Badran et al. (2008), Abd-Elmola (2014) and Badran et al. (2016) on Sterculia diversifolia, Dalbergia sissoo, Koelreuteria paniculata, poplar and Moringa oleifera, respectively were in close agreement with our results.

Table 4. Effect of NPK and micronutrient fertilization treatments on nitrogen, phosphorus and potassium percentages of Delonix regia seedlings during 2016 and 2017 seasons.

\begin{tabular}{|c|c|c|c|c|c|c|c|c|}
\hline \multirow{3}{*}{$\begin{array}{l}\text { Micro nutrient } \\
\text { treatments (B) }\end{array}$} & \multicolumn{8}{|c|}{ NPK fertilization rates (A) } \\
\hline & \multicolumn{4}{|c|}{$1^{\text {st }}$ season (2016) } & \multicolumn{4}{|c|}{$2^{\text {nd }}$ season $(2017)$} \\
\hline & $\mathbf{N}_{1} \mathbf{P}_{1} \mathbf{K}_{1}$ & $\mathbf{N}_{2} \mathbf{P}_{2} \mathbf{K}_{2}$ & $\mathbf{N}_{3} \mathbf{P}_{3} \mathbf{K}_{3}$ & Mean (B) & $\mathbf{N}_{1} \mathbf{P}_{1} \mathbf{K}_{1}$ & $\mathbf{N}_{2} \mathbf{P}_{2} \mathbf{K}_{2}$ & $\mathbf{N}_{3} \mathbf{P}_{3} \mathbf{K}_{3}$ & Mean (B) \\
\hline \multicolumn{9}{|c|}{ Leaves nitrogen (\%) } \\
\hline Control & 2.43 & 2.55 & 2.59 & 2.52 & 1.96 & 2.15 & 2.24 & 2.12 \\
\hline Mn $25+$ Zn 25 & 2.48 & 2.59 & 2.64 & 2.57 & 1.99 & 2.22 & 2.26 & 2.16 \\
\hline Mn $50+$ Zn 50 & 2.51 & 2.67 & 2.69 & 2.62 & 2.10 & 2.30 & 2.30 & 2.23 \\
\hline Mn $75+$ Zn 75 & 2.58 & 2.71 & 2.73 & 2.67 & 2.13 & 2.28 & 2.35 & 2.25 \\
\hline Mn $100+$ Zn 100 & 2.56 & 2.65 & 2.68 & 2.63 & 2.03 & 2.26 & 2.32 & 2.20 \\
\hline Mean (A) & 2.51 & 2.63 & 2.67 & & 2.04 & 2.24 & 2.29 & \\
\hline L.S.D. at $5 \%$ & A: 0.08 & & 0.06 & AB: 0.10 & A: 0.11 & & 0.08 & AB: 0.14 \\
\hline \multicolumn{9}{|c|}{ Leaves phosphorus (\%) } \\
\hline Control & 0.328 & 0.351 & 0.356 & 0.345 & 0.271 & 0.302 & 0.308 & 0.294 \\
\hline Mn $25+$ Zn 25 & 0.333 & 0.355 & 0.360 & 0.349 & 0.278 & 0.312 & 0.317 & 0.302 \\
\hline Mn $50+$ Zn 50 & 0.336 & 0.362 & 0.365 & 0.354 & 0.281 & 0.319 & 0.322 & 0.307 \\
\hline Mn $75+$ Zn 75 & 0.340 & 0.364 & 0.369 & 0.358 & 0.285 & 0.325 & 0.330 & 0.313 \\
\hline Mn $100+$ Zn 100 & 0.332 & 0.357 & 0.363 & 0.351 & 0.279 & 0.313 & 0.321 & 0.304 \\
\hline Mean (A) & 0.334 & 0.358 & 0.363 & & 0.279 & 0.314 & 0.320 & \\
\hline L.S.D. at $5 \%$ & A: 0.010 & & N.S. & AB: N.S. & A: 0.01 & & : N.S. & AB: N.S. \\
\hline \multicolumn{9}{|c|}{ Leaves potassium (\%) } \\
\hline Control & 2.76 & 2.98 & 3.04 & 2.93 & 2.23 & 2.42 & 2.46 & 2.37 \\
\hline Mn $25+$ Zn 25 & 2.81 & 3.04 & 3.07 & 2.97 & 2.29 & 2.51 & 2.56 & 2.45 \\
\hline Mn $50+$ Zn 50 & 2.83 & 3.10 & 3.14 & 3.02 & 2.33 & 2.58 & 2.66 & 2.52 \\
\hline Mn 75 + Zn 75 & 2.88 & 3.16 & 3.21 & 3.08 & 2.40 & 2.62 & 2.69 & 2.57 \\
\hline Mn $100+$ Zn 100 & 2.86 & 3.11 & 3.13 & 3.03 & 2.38 & 2.57 & 2.64 & 2.53 \\
\hline Mean (A) & 2.83 & 3.08 & 3.12 & & 2.33 & 2.54 & 2.60 & \\
\hline L.S.D. at $5 \%$ & A: 0.09 & & 0.07 & AB: 0.12 & A: 0.12 & & 0.08 & AB: 0.14 \\
\hline
\end{tabular}


Leaves \% of $\mathrm{N}, \mathrm{P}$ and $\mathrm{K}$ were gradually increased parallel to the increase in the used micronutrient rates up to $\mathrm{Mn} 75 \mathrm{ppm}+\mathrm{Zn}$ $75 \mathrm{ppm}$, in the two seasons, in comparison with control treatment. However, the differences were significant for $\mathrm{N}$ and $\mathrm{K} \%$ only as shown in Table (4). On the line with these results were those reported by Aly et al. (1994), Ahmed (1995) and Ahmed and Aly (1998) on Leucaena; Al-Humaid (1998) on rose and Mahdy (2002) on Albizzia lebbek.

Table (4) shows that the interaction between NPK and $\mathrm{Mn} / \mathrm{Zn}$ treatments was significant only with $\mathrm{N} \%$ and $\mathrm{K} \%$, with the best results being given by either the medium or the high NPK rate in combination with 75 Mn ppm + 75 ppm Zn.

The importance of $\mathrm{N}, \mathrm{P}$ and $\mathrm{K}$ elements in inducing vegetative growth parameters, as well as, chemical composition of Delonix regia seedlings could be recognized in the light of their well-known physiological roles in plant growth and development. Meanwhile, Takei et al. (2001) revealed that $\mathrm{N}$ availability in the root zone may initiate cytokinins to be transported across the roots to the shoots. Moreover, Bravdo (2000) stated that the differences in the mobility of various elements expose the roots of the plant to a wide range of mineral availability and rapid branching of small rootlets which reflect, by sequence, in better growth of the different plant parts.

Concerning the two microelements, manganese has an important role in photosynthesis as it is involved in the sequences of reactions by which electrons are derived from water and oxygen is liberated. It is widely involved in catalytic roles in plants such as krebs cycle and nitrogen metabolism. It may also have a structural role in chloroplasts which become light sensitive in its absence and ultimately lose their structure under conditions of extreme Mn shortage (Delvin, 1975 and Bidwell, 1974). Zinc on the other hand, is involved in the biosynthesis of the plant auxin, indole-3-acetic acid and as such its deficiency may produce shortened, stunted plants with poorly developed apical dominance. It is also an obligatory activator of a number of important enzymes and involved in protein synthesis (Devlin, 1975 and Bidwell, 1974).

\section{REFERENCES}

Abd-Elmola, M.A. (2014). Physiological Studies on Poplar Trees. M.Sc. Thesis, Fac. of Agric., Minia Univ.

Abdou, M.A.H.; Ahmed, E.T.; Taha, R.A. and Helmy, S.M. (2006). Response of Khaya senegalensis to some bio. and chemical fertilization treatments. Minia J. Agric. Res. \& Dev., 26 (3) : 427-448.

Ahmed, A.A. (1995). Some Agricultural Treatments Affecting Seed Germination and Seedlings Growth of Leucaena leucocephala, Lam. Ph.D. Thesis., Fac. Agric., Minia Univ.

Ahmed, E.T. and Aly, M.K. (1998). Response of five Leucaena species grown in sandy calcareous soil to fertilization with macro and micro nutrients. J. Agric. Sci., Mansoura Univ., 23(9):3935-3951.

Al-Humaid, A.I. (1998). The influence of foliar nutrition and gibberellic acid application on the growth and flowering of Sntrix rose. Sec. Conf. of Ornam. Hort., Ismailia, Egypt, pp. 245.

Ali, N.F. (2005). Effect of some Agricultural Treatments on the Growth and Chemical Composition of Sterculia diversifolia Seedlings. M.Sc. Thesis, Fac. Agric. Minia Univ.

Aly, M.K.; Abdalla, N.M.; Badran, F.S. and Ahmed, A.A. (1994). Response of Leucaena leucocephala grown in two soil types to macro and micro fertilization treatments. II. Chemical composition. Minia J. Agric. Res. \& Dev., 16(3):747769. 
Badran, F.S.; Abdou, M.A.H. and Aly, M.K. (1989). Response of growth and chemical composition of Luffa cylindrica for Mn, $\mathrm{Zn}$, alar and CCC soaking treatments. Minia J. Agric \& Dev., 11(3):1109-1121.

Badran, F.S.; Abdou, M.A.H.; Aly, M.K.; Sharaf-Eldeen, M.N. and Mohamed, S.H. (2003). Response of sandy soil-grown Acacia saligna seedlings to organic, bio. and chemical fertilization and IAA treatments. Proc. First Egyptian-Syrian Conf., Minia, Egypt, p. 109.

Badran, F.S.; Abdou, M.A.H.; Taha, R.A. and Ibrahim, S.I. (2008). Partial replacement of chemical fertilizers by biofertilizers in producing Koelreuteria paniculata seedlings. Proc. $1^{\text {st }}$ Inter' $n$ in Sci. Conf. on Ornamentals, Alex. J. Agric. Res., 53:35-40.

Badran, F.S.; Aly, M.K.; Abdalla, N.M. and Ahmed, A.A. (1994). Response of Leucaena leucocephala grown in two soil types to macro and micro fertilization treatments. I. Vegetative growth and photosynthetic pigments. Minia J. Agric. Res \& Dev., 16(3):723-746.

Badran, F.S.; Taha, R.A.; El-Ghadban, E.A. and El-Sagheir, M.M. (2016). Effect of irrigation intervals and organic/mineral fertilization treatments on vegetative growth and chemical composition of Moringa oleifera plants. Minia J. Agric. Res. \& Dev., 36(2):177-191.

Bidwell, R.G.S. (1974). Plant Physiology, Macmillan Publishing Co., Inc., New York, U.S.A.

Bravdo, B.A. (2000). Physiological aspects connected with drip irrigation. Rivista de Frutticoltural di Ortofloricoltura, 62 (718):18-20. CAB Online Abst. J. 2000 (191): 6442.
Devlin, R.M. (1975). Plant Physiology, $3^{\text {rd }}$ Edition, Affiliated East West Press, New Delhi, Chap. 10 \& 11:159-205.

El-Sayed, A.A.; Aly, M.K.; Abd-Eldayem, A.M. and Mostafa, H.I. (2006). Influence of soil type and NPK fertilization treatments on growth and chemical composition of Dalbergia sissoo, Roxb. and Parkinsonia aculeate, L. seedlings. Minia J. Agric. Res. \& Dev., 26(1):131150.

Little, I.M. and Hills, F.J. (1978). Agricultural Experimentation, Design and Analysis. John Wiley \& Sons Inc. New York, U.S.A.

Mahdy, H.A. (2002). Effect of Some Fertilization Treatments on Some Ornamental Tree Seedlings M.Sc. Thesis, Fac. of Agric., Minia Univ.

Page, A.L.; Miller, R. H. and Kenney. D.R. (1982). Methods of Soil Analysis, Part II, Amer. Soc. Agronomy Inc., Madison, Wisconsin, U.S.A.

Shetta, N.D.; El-Sayed,W.B.; Nasr, T.A. and Shaarawy, N.M. (2014). Influence of mineral fertilization with NPK and methods of inoculation on seedling growth of two woody legume trees. World Appl. Sci. J., 29 (7):825-834.

Taha, R.A. (1994). Seed germination and seedling growth of some ornamental trees. M.Sc. Thesis, Fac. Agric., Minia Univ.

Takei, K.; Sakakibara, H.; Taniguchi, M. and Sugiyama, T. (2001). NitrogenDependent accumulation of cytokinins in root and translocation to leaf. Plant \& Cell Phys., 42(1):85-93. 
تأثير التسميد بالعناصر الكبرى NPK والعناصر الصغرى على شتلات البوانسيانا في الأراضي الرملية

$$
\text { محمود عبد الهادي حسن عبده و فاروق صلاح الدين عبد الرحمن بدران }
$$

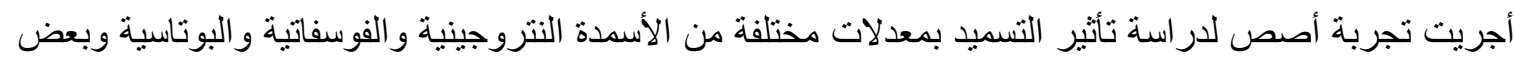

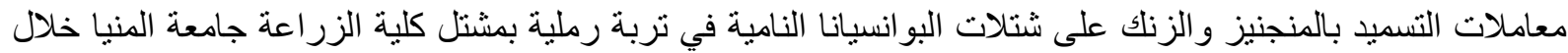

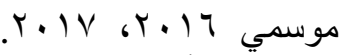

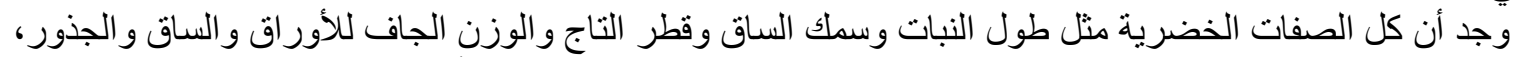

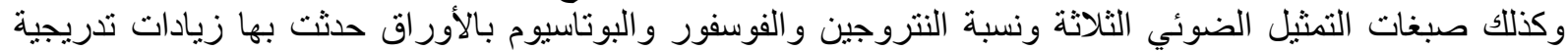

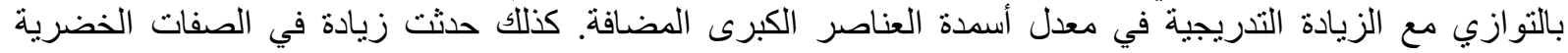

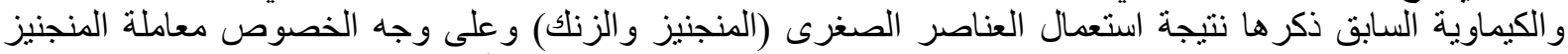

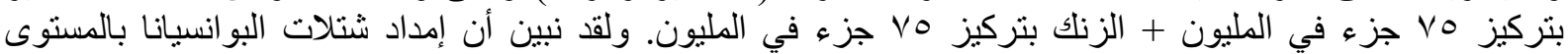

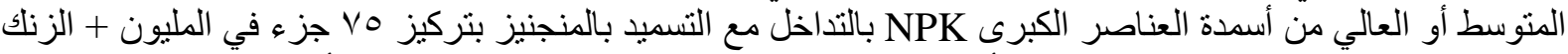

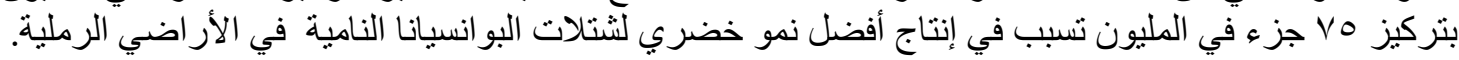

